\title{
A alegoria nos sermiess de Padre Antônio Vieira: algumas questöes sobre seu emprego e terminologia
}

Allegory in Father Antonio Vieira's sermons: some questions on its use and terminology

Marcus De Martini ${ }^{1}$

RESUMO: Neste artigo, discute-se o conceito de alegoria, bem como dos termos correlatos "tipo" e "figura", dentro da tradição da hermenêutica cristã, a fim de compreender seu uso nos sermões de Padre Antônio Vieira. Partindo-se então da constatação de que a terminologia pode ser insuficiente para compreender os diversos usos implicados pelos conceitos, na esteira de Young (1997), optamos por empregar subsidiariamente a noção de “estratégias de leitura" como ferramenta para mapear os diversos usos da alegoria como forma de interpretação. Por meio de uma amostragem qualitativa dos sermões de Vieira, constata-se o uso variado desses termos pelo jesuíta e a pertinência de compreender as estratégias alegóricas empregadas por ele para construir retórica e teologicamente seus sermões.

Palavras-chave: Padre Antônio Vieira. Sermão. Alegoria. Tipologia.

ABSTRACT: In this article, I discuss the concept of allegory, as well as the related terms 'type' and 'figure' amid the Christian hermeneutical tradition, in order to understand their use in Father Antonio Vieira's sermons. Stemming from the assumption that the terminology may be insufficient to comprehend the multifarious use implied by these concepts, we opt to subsidiarily employ the notion of "reading strategies", based on Young (1997), as a tool to map the various uses of allegory as a means of interpretation. Through a qualitative sampling of Vieira's sermons, we show the varied use of this terms and the pertinence of comprehending the allegorical strategies employed by the Jesuit to rhetorically and theologically compose his sermons.

Keywords: Father Antonio Vieira. Sermon. Allegory. Typology.

1 Doutor em Estudos Literários pela Universidade Federal de Santa Maria (UFSM), professor do Departamento de Letras Vernáculas e do Programa de Pós-graduação em Letras da mesma instituição. 


\section{Introdução}

As discussões acerca do tema "alegoria" e, por extensão, acerca da exegese bíblica são antigas e a literatura correspondente é imensa. Inicialmente, é bom ressaltar que a maioria dos autores usa a noção de alegoria em dois sentidos: a alegoria como forma de composição poético-retórica (a "alegoria dos poetas") e a alegoria como forma de interpretação (a "alegoria dos teólogos"). Em decorrência disso, a literatura sobre o assunto aponta para os dois lados. Há diversos textos que trabalham com o conceito teológico de alegoria, como há tantos outros que se preMarcus ocupam mais com o emprego literário do conceito. No entanto, devido De Martini à própria origem da "alegoria”, grande parte dos estudos apresentam uma convergência das duas abordagens ${ }^{2}$.

Ligados à noção de alegoria, estão ainda os conceitos de figura e tipo, como veremos. Assim, tem-se um emprego variado na literatura desses termos que ora parecem ser sinônimos, ora não. Esse uso variado dos termos pode causar confusão no estudioso especialmente de textos anteriores à modernidade.

Assim, se, por um lado, tem-se a necessidade de primar-se por um rigorismo terminológico; por outro, é preciso reconhecer o caráter esquivo e proteico do termo "alegoria". Nesse sentido, no presente texto, busca-se traçar uma "arqueologia" da noção de alegoria e dos termos correlatos "figura" e "tipo", tendo como base os sermões de Padre Antônio Vieira, na esteira do que preconiza o crítico brasileiro João Adolfo Hansen (1997), mas também, reconhecendo a ocasional putatividade dos termos, procura-se atentar para os usos variados dos mesmos termos, caso a caso, na esteira de Frances M. Young (1997), para se esboçar um breve panorama da terminologia e dos usos desses termos no Seiscentos, em Portugal.

\section{Alegoria/Tipo/Figura: breve histórico}

Para se abordar o uso desses termos na sermonística de Vieira, é preciso iniciar com o seu uso no contexto cristão, com a chamada "alegoria dos teólogos", à qual daremos mais atenção.

Como afirma Jean Daniélou, a questão da leitura "alegórica" da Bíblia surgiu como uma resposta às polêmicas dos cristãos com os judeus e os gnósticos acerca do lugar do Antigo Testamento (AT) diante

2 Para uma abordagem abrangente e compreensiva do tema em língua portuguesa, remetemos o leitor à obra de João Adolfo Hansen (2006). Para uma visão sintética e para uma coletânea da bibliografia mais importante acerca do assunto na área de Literatura, é válido o artigo de Carlos Ceia (1998). 
do advento de Cristo. Assim, o ponto inicial para compreender a exegese cristã parte do próprio Antigo Testamento (MONTAGUE, 2007, p. 15-6). A questão que então surgia era se os escritos judaicos não eram de fato dispensáveis, frente a toda a florescente literatura cristã. Tal seria a colocação de Marcião (c. 85 - 160 d.c) e dos gnósticos. No entanto, Irineu (c. 130 - 202) respondeu a isso a partir do uso que fez de três termos que pegara emprestado da retórica: hipótese, economia e recapitulação. $\mathrm{Na}$ antiga tradição retórica, hipótese se referia ao assunto do texto. De acordo com O'Keefe e Reno (2005, p. 25 e segs.), os primeiros intérpretes da Bíblia como que descobriam "fórmulas ocultas" nos textos ao compararem várias passagens que apresentavam semelhanças entre si. Tais semelhanças compunham essas espécies de fórmulas, o que, com o tempo, passou a ser chamado de sentido espiritual das es-

A alegoria nos sermões de Padre Antônio Vieira crituras. Assim, segundo Irineu, a descoberta desse padrão implícito às Escrituras indicava uma hipótese, um tema que fazia todo o conjunto de textos possuir sentido. Daí a importância do conceito de economia, que se referia à correta ordem e arranjo das coisas e, no caso da retórica, do enredo de uma narrativa ou ainda dos argumentos em um discurso. Para Irineu, a economia divina repousava na existência de um Deus criador e ordenador de tudo, que delineara uma sequência de eventos inter-relacionados que redundaria em Cristo, cuja vinda esclareceria essa própria economia. Como afirma Irineu, em Cristo houve a recapitulação de todas as coisas, termo que, em retórica, referia-se ao argumento final de um discurso. Em Cristo, as profecias do Antigo Testamento haviam se cumprido. Portanto, como concluem O'Keefe e Reno (ibid., pp. 28 e 41), a característica mais singular da exegese patrística é a pressuposição de que conhecer a identidade de Jesus Cristo é a base para a correta leitura dos escritos sagrados do povo de Israel. Cristo não era então a Bíblia, mas a sua hipótese. Por isso, conforme afirma Northrop Frye (1982, p. 78), a busca da confirmação da verdade de Cristo a partir da relação de sua história com as profecias do Antigo Testamento, como também a confirmação dessas próprias profecias com a vida de Jesus, caracterizaria um jogo de espelhos. Os dois testamentos formariam um espelho, em que um refletiria o outro, mas nenhum deles o mundo exterior.

A união entre o Antigo e o Novo Testamento (NT), entre as profecias e a sua realização, já havia sido mencionada por Jesus, conforme Lucas 4,18. Segundo C.R. Evans (1995, p. 49), é dessa relação que surge a leitura figural. A maneira mais comum de compreender a relação entre os 
dois testamentos, ainda segundo Evans, é a de ver a verdade como encoberta no Antigo Testamento, sendo que o Novo teria retirado o véu sobre essa verdade. Daí viria a imagem de Cristo como "o que traz a luz"3.

No caso cristão, o caminho para a exegese passou a ser traçado a partir de Paulo. Duas passagens bíblicas são importantes para a compreensão do início do uso da exegese figural, ou do que passou a ser conhecido pelo termo tipologia. A primeira é Rom 5,14, onde o apóstolo afirma que Adão era um typos ${ }^{4}$ de Cristo. Cristo teria vindo como um "Segundo Adão", para resgatar o que havia sido perdido com o primeiro: o ParaMarcus íso. A segunda é 1 Cor 10,1-11, em que afirma que eventos do passado, De Martini especificamente do tempo de Moisés, haviam se sucedido como "figuras", para que não fossem repetidos depois. Em ambas as passagens, o emprego do termo typos e de seus derivados serve para relacionar eventos do AT com os do NT. Em ambas, o que se relaciona são eventos, e não palavras simplesmente. Acima de tudo, a tarefa de Paulo não é a de repetir o AT, mas de usá-lo para acrescentar algo de novo (cf. GOPPELT, 1982, p. 218 e segs.).

A palavra typos é o principal substantivo que se origina de túptein, "golpear", e possui o sentido básico no grego clássico de um "golpe", ou da "marca" deixada pelo golpe. Por isso, um dos usos mais frequentes era o da "impressão" feita em cera por um selo, ou seja, aqui há a ideia de um modelo e o de uma cópia, ainda que não idêntica, mas que certamente mantém uma correspondência com sua matriz ${ }^{5}$. É esse o sentido mais empregado por Paulo6.

Assim, segundo Galdon, podemos definir tipologia da seguinte forma:

\footnotetext{
Cf. 2 Cor 3.

Optamos, no presente texto, por transliterar os termos gregos, a fim de facilitar a leitura.

Esses dois principais usos podem ser ilustrados por uma passagem do discurso de Estevão (Atos 7,43-4): “Antes tomastes o tabernáculo de Moloque, E a estrela do vosso deus Renfã, Figuras [túpous] que vós fizestes para as adorar. Transportar-vos-ei, pois, para além da Babilônia. Estava entre nossos pais no deserto o tabernáculo do testemunho, como ordenara aquele que disse a Moisés que o fizesse segundo o modelo [túpon] que tinha visto". Como afirma Woolcombe, "curiosamente, esses dois versos citam as únicas duas passagens no Antigo Testamento nas quais túpos ocorre: Amós 5,26 e Êxodo 25,40. No primeiro caso, a palavra significa 'uma imagem gravada'; no segundo, um 'padrão' ou 'modelo"” (1957, p. 61, tradução nossa).

6 Cf. GOPPELT, Op. Cit., p. 221-2; WOOLCOMBE, op. cit., p. 60-1; GALDON, op. cit., p. 19. Woolcombe afirma que: "nesse momento, precisamos apenas expor a conclusão de que, apesar das enormes diferenças entre São Paulo e autores contemporâneos a ele, a palavra túpos invariavelmente possui o sentido primário de 'modelo' ou 'padrão'. Deveríamos, portanto, adotar a interpretação de Rom. 5 de A. Nygren: ‘Adão é chamado de túpos, um padrão ou modelo para Cristo”' (op. cit., p. 65, tradução nossa).
} 
A tipologia revela essa correspondência entre as pessoas, os eventos e as coisas do Antigo Testamento e as pessoas, os eventos e as coisas do Novo Testamento. Essa correspondência está presente porque Deus controla o todo da história, e é Deus quem faz com que os primeiros indivíduos, grupos e eventos apresentem características que prenunciam eventos posteriores. Algumas "coisas" sobre as quais o texto das Escrituras literalmente fala são também usadas por Deus para prefigurar outras coisas no futuro. (...)

A alegoria nos sermões de Tipologia pode, portanto, ser definido como o método de interpretação das Escrituras em que as pessoas e os eventos, os incidentes e as narrativas do Antigo Testamento, o Antigo Testamento res ipsae, são vistos como realidades que são ao mesmo tempo sinais proféticos e prenúncio de pessoas e eventos no plano redentor de Deus assim como ele é preenchido e revelado no Novo Testamento. (GALDON, op. cit., p. 23, tradução nossa.)
Padre Antônio

Vieira

93

É preciso então esclarecer o uso do termo "tipo" e do termo "antitipo". O emprego deste último não é unânime na literatura antiga, ocorrendo duas vezes no NT: uma em Hebreus 9,24, onde o sentido se assemelha ao de tipo, e em 1 Pedro 3,21, em que Cristo é apresentado como o tipo revelador, o padrão para a compreensão do que se encontrava prefigurado no AT e também dos eventos atuais ou "pós-figurações". Esse último conceito foi o adotado pelos Padres da Igreja. Nesse sentido, "anti" significa "no lugar de", "substituindo", que é o sentido principal de "anti". Portanto, para os Padres da Igreja, chamar Cristo de antitipo significa identificá-lo como o tipo central, no qual todos os outros tipos, anteriores ou posteriores a ele, encontram seu preenchimento (cf. O'KEEFE e RENO, op. cit., p. 81)7.

Segundo Galdon (op. cit., p. 30-1), os estudiosos das escrituras sempre ressaltaram que a tipologia se baseia nas coisas - res ipsae - e não sobre as palavras - verba - das escrituras. Por coisas, entendem-se pessoas ou eventos. Ainda que o tipo signifique o antitipo, e o antitipo preencha o tipo, essa significância e preenchimento não destroem

7 Para Galdon, "tipo, como antitipo, são termos ambíguos, pois podem ser aplicados tanto para a primeira ou a segunda imagem. No entanto, geralmente, tipo é usado para a "sombra" veterotestamentária, enquanto que antitipo se refere a seu cumprimento no Novo Testamento" (op. cit., p. 20, tradução nossa). 
a sua própria realidade, mas simplesmente adicionam um sentido mais profundo às pessoas, lugares, coisas ou eventos do Antigo Testamento e liga-as às pessoas, coisas, lugares ou eventos do Novo Testamento. Tipo e antitipo são espirituais somente em relação ao significado que eles incorporam no contexto referencial de sombra e preenchimento. Em si mesmos, eles permanecem coisas reais, não abstrações. Moisés, Josué, Isaac e Adão são sombras de Cristo, mas Moisés, Josué, Isaac e Adão também são personagens reais.

Voltando a Paulo, vimos que o apóstolo já propunha uma interMarcus pretação que fugia do sentido literal, a que chamamos tipológica. No De Martini entanto, em Gálatas 4,24, Paulo apresenta os filhos de Agar e Sara como as prefigurações dos judeus e dos cristãos. Ismael, filho de Agar, a qual seria uma alegoria da "Jerusalém terrestre", teria "nascido da carne", enquanto que Isaac, nascido de Sara, a qual, por sua vez, representaria a Jerusalém celeste, teria nascido pela graça divina e seria, portanto, uma alegoria da nova aliança pela liberdade a ser alcançada na fé de Cristo (cf. O'KEEFE e RENO, op. cit., p. 90-1). Contudo, segundo Simonetti (op. cit., p. 12), ao afirmar que isso "se entende por alegoria", Paulo mostra que compreende tipo como sinônimo de alegoria. ${ }^{8}$

A noção de alegoria também possui uma origem grega. Para Whitman (1987, p. 20), a alegoria já se encontrava prenhe desde Homero, pois havia, especialmente na Ilíada, a tendência de se personificar as emoções, como no caso da raiva que acomete Aquiles logo na primeira cena dessa epopeia. Ainda que a obra de Homero seja considerada refratária à alegoria, pois, como ensina Auerbach (1994), há ali a primazia da objetividade, é inegável que havia a possibilidade de que se desenvolvesse a partir dessa tendência à personificação uma leitura alegórica, isto é, extrapolando o sentido meramente literal, objetivo, do texto.

Os gregos não possuíam textos sagrados como os judeus e cristãos, mas possuíam textos que quase chegavam a esse status, como os de Homero, por exemplo. A obra homérica, como a de outros poetas, também era submetida a exegeses. Havia a interpretação literal, como também a alegórica (allegoria/allegorein: dizer uma coisa para significar outra). Desde 550 a.C., com Ferécides de Siros (séc. VI a.C.), e depois com Teágenes de

\footnotetext{
8 Segundo Galdon (op. cit., p. 25), a palavra typos ocorre 16 vezes no NT e 11 vezes em São Paulo, mas, curiosamente, a palavra alegoria é o termo usado com mais frequência por Paulo para se referir ao conceito de tipologia, e o termo alegoria, em vez de tipologia, é a palavra mais comumente usada pelos Padres da Igreja ao se referirem a esse método de interpretação escritural.
} 
Régio (séc. VI a.C.), procurou-se compreender algumas histórias contadas por Homero, e que contrariavam, sobretudo, alguns valores morais, a partir de outra ótica. Acreditava-se que essas histórias eram tão absurdas que deveriam possuir outro sentido9. Depois do século IV a.C., o alegorismo se torna especialmente associado com os estoicos, e Crísipo de Soli (280 - 207 a.C.) emerge como seu principal expoente ${ }^{10}$. Seja para exemplificar as próprias doutrinas cosmológicas, como os estoicos, seja para negar acusação de imoralidade nos poemas homéricos, o fato é que ambas as tendências procuravam encontrar teorias filosóficas subjacentes aos textos do grande poeta grego, o que era a verdade do texto, oculta por um véu de fantasia, destinado apenas ao entretenimento. Essa verdade, por sua vez, era universal, eram os princípios do mundo, e encontrá-los era a tarefa dos filósofos (WHITMAN, 1987, p. 20). Esse tipo de interpretação

A alegoria nos sermões de Padre Antônio Vieira 95 vai florescer em meio à corrente helenizante do judaísmo em Alexandria, especialmente no trabalho de Fílon.

É por essa razão que Auerbach (1994) afirma que, apesar de os relatos bíblicos apresentarem-se como retalhos, horizontalmente independentes, eles possuem uma coerência vertical, unidos justamente pela ideia de Deus e de sua providência. Assim, o valor histórico dos acontecimentos do Velho Testamento foi perdendo terreno perante seu valor "simbólico"; os acontecimentos veterotestamentários passaram a ser interpretados como eventos que antecipavam o aparecimento de Cristo, como figuras (termo latino equivalente ao "typos" grego). Segundo Auerbach, esse conceito, que originalmente significava "forma plástica", foi paulatinamente se desligando desse sentido mais concreto, deslocando-se para um sentido totalmente abstrato. Como vimos, devido à helenização da cultura romana, no século I, especialmente ao estudo da retórica de Quintiliano (35 - 95 d.C.), quando o conceito de figura passou a ser ligado ao de "figura de linguagem". Os padres da Igreja, por sua vez, dariam um sentido totalmente diverso ao termo. Tertuliano (c. 160 - c. 220 d.c) foi o primeiro a empregar o termo em seu novo sentido. Segundo Auerbach, a partir do uso que fizeram desse conceito os Padres da Igreja, a partir do século I, figura passa a ser "algo

9 Esse tipo de exegese é que vai começar a relacionar, por exemplo, o deus Cronos com "chronos" ("tempo", em grego). Metrodoro de Lâmpsaco (331-278 a.C.), em seu tratado sobre Homero, vai relacionar alegoricamente os deuses olímpicos a elementos da natureza (WOOLCOMBE, 1957, p. 50-1).

10 Segundo Woolcombe, "o alegorismo grego tinha dois propósitos distintos: a) desenterrar os significados mais profundos, ou implícitos, que subjaziam sob os mitos homéricos e b) defender os mitos de acusações de imoralidade e blasfêmia" (Ibidem, p. 51, tradução nossa). 
real e histórico que anuncia alguma outra coisa que também é real e histórica. A relação entre os dois eventos é revelada por um acordo de similaridade". Assim, um evento do Antigo Testamento, por exemplo, é figura de um evento do Novo Testamento pela semelhança entre os dois. O segundo evento "preenche" o primeiro (a figura), tornando claro um significado antes oculto; Josué "prefigura" Jesus, ou seja, "o nome Josué-Jesus é uma profecia fenomenal ou prefiguração do futuro Salvador" (AUERBACH, 1997, p. 27) ${ }^{11}$.

Segundo Henri de Lubac (1947, pp. 180-226), o primeiro autor pagão Marcus a empregar a palavra alegoria para a interpretação de textos foi PlutarDe Martini co (46-126 d.c.), usando-a em substituição ao termo grego "uponoiai"12, referente aos sentidos ocultos nos escritos dos antigos. Assim, segundo o autor francês, o termo alegoria, conforme empregado então por Plutarco, é provavelmente de origem judaico-cristã, mais especificamente paulina. Paulo teria então utilizado o termo grego, alterando, contudo, o seu sentido corrente para criar um novo conceito, que não possuía antecedentes tanto no mundo grego quanto no mundo judaico. Do mesmo modo, "tipo" ou "figura" também são termos paulinos; porém, eles se referem a apenas um dos dois termos cuja ligação é estabelecida através da alegoria. Portanto, para Lubac, a interpretação alegórica, em seu sentido tradicional, consiste em discernir os tipos ou as figuras que, em Israel, anunciavam o Cristo. É através da alegoria que se estabelece a relação da figura com a verdade, da letra com o espírito, do antigo com o novo. Ademais, como continua o mesmo autor, há uma variação muito grande na nomenclatura do que chamamos de alegoria ou tipo por parte dos Padres da Igreja, sendo que vários sequer empregam nenhum desses dois termos. De qualquer forma, o termo mais frequente sempre é alegoria. Sejam divididos os sentidos das Escrituras em dois, três ou quatro, é sempre chamado de sentido alegórico aquele que trata do "sacramenta Christi et Ecclesiae". Por fim, São Tomás de Aquino, no artigo 10 da primeira questão da Suma, expõe de forma clara e precisa, usando as palavras mais tradicionais, uma doutrina de 12 séculos, em que se afirma a originalidade da alegoria cris-

11 Conforme ilustra João Adolfo Hansen, “Auerbach escreve que, no caso da alegoria verbal ou do simbolismo religioso, pelo menos um dos dois elementos que se combinam é puro signo, ao passo que na relação tipológica ou figural os fatos significante e significado - a coisa passada e a coisa futura, o homem do passado e o homem do futuro - são postulados como entes históricos e reais. Assim, por exemplo, numa alegoria do amor, pelo menos um dos termos não é acontecimento histórico, mas apenas signo e, como tal, uma abstração" (2006, p. 106).

12 Esse termo já era encontrado em Platão e Xenofonte, pelo menos (LUBAC, 1947, p. 183). 
tã. Segundo Aquino, o sentido espiritual da bíblia se divide em três; lição essa que será repetida até o século XIX, passando por autores da Contrarreforma, como Salmerón e Cornélio a Lápide, autores que estão entre os mais mencionados por Vieira ${ }^{13}$.

Frances V. Young concorda com Lubac quanto ao fato de o termo tipologia ser uma construção moderna, já que os exegetas antigos não distinguiam claramente entre tipologia e alegoria ${ }^{14}$. Assim, ainda segundo Young, a afirmação moderna de que a tipologia é diferente da alegoria, uma afirmação que requer a realidade histórica de um evento como uma

A alegoria nos sermões de Padre Antônio Vieira carga eminentemente cristã, o que não ocorre com a alegoria (LUBAC, op. cit., p. 29-33). Contudo, o mesmo autor opta por "sentido espiritual", por julgá-lo mais amplo e mais de acordo com o evento Cristológico, já que a relação do AT com o NT não é apenas entre promessa e cumprimento, entre dois eventos históricos correlativos (tipologia), mas também é uma mudança espiritual para os seguidores de Cristo, portador do Espírito da Verdade, que é o próprio espírito do Cristo.

Contrariando grande parte da literatura sobre a exegese cristã, especialmente sobre a exegese patrística, Frances M. Young, em Biblical Exegesis and the formation of the Christian Culture, vai propor uma compreensão diferente dos procedimentos que comumente são entendidos como alegóricos ou tipológicos, abrindo novas possibilidades para o entendimento desses fenômenos.

Como vimos, na Antiguidade, supunha-se que a linguagem se referia a outra coisa além dela mesma, assim, diferentes expressões verbais poderiam se referir às mesmas coisas de um modo que palavras poderiam ser traduzidas ou interpretadas pela substituição de uma diferente forma de expressão. 0 significado da linguagem está na ideia detrás das palavras, na realidade à qual se refere a linguagem. Desse modo, a questão fundamental para a compreensão do significado era discernir o referente (YOUNG, op. cit., pp. 120 e segs.).

13 No mesmo sentido, Galdon (op. cit., p. 25-6, tradução nossa): "para os Padres da Igreja, como também para Aquino, não havia realmente diferença entre os conceitos de alegoria e tipologia, sendo ambos apenas variações do sentido espiritual".

14 Henri de Lubac, no mesmo sentido, confirma que a palavra "tipologia" é uma criação não encontrada nos Padres da Igreja, sendo considerada como sinônimo de alegoria por Aquino. Para Lubac, a expressão parece ter uma origem luterana (1966, p. 28, n. 3). 
Buscando a definição de tipo conforme desenvolvida por Melito de Sardis, bispo do século II d.C., Young mostra como essa definição se encontrava próxima da ideia de um modelo, como já vimos. Portanto, para a autora, há essencialmente uma intenção mimética no tratamento que Melito dava à escritura. A realidade estava no preenchimento, e não no evento passado. Assim, para Young, Melito parece estar introduzindo uma forma de profecia que se encontra intimamente relacionada com a mímese, isto é, com a representação e o modelo. A autora nota que o uso de antitipo no NT - termo não encontrado no mundo helênico Marcus fora do contexto bíblico-cristão no sentido empregado aqui - está relaDe Martini cionado a eventos escatológicos, a uma realidade transcendente, como em Hebreus 9,24 e I Pedro 3,20-1. De algum modo, continua Young, é como se uma "impressão" do futuro se encontrasse marcada nas Escrituras. Os oráculos deixam de ser apenas enigmas para se tornarem "representações" ("representations") do que estaria por vir. Assim, o elemento mimético seria o que faria um "tipo".

Young então apresenta quatro categorias amplas de tipos na exegese patrística, sendo que todas, em algum sentido, criam intersecções entre tempo e eternidade, particular e universal: 1) exemplar (biográfica - potencialmente "universal"); 2) profética (ou "histórica" - prefiguração narrativa); 3) espacial ou geográfica e 4) recapitulativa (cosmológica/escatológica).

Assim, a tipologia não é algo único. Young conclui então que abordar a exegese patrística a partir dos "sentidos" da Escritura não é algo muito produtivo. Para a autora, o que é interessante é compreender o método através do qual se faz a exegese, ou, como ela mesma chama, as "estratégias de leitura". Young então enumera pelo menos seis.

A primeira é a leitura parenética. Nos círculos cristãos, a palavra de Deus sempre foi vista como um guia para a vida, com os textos escriturais apresentando ensinamentos de valor moral. Tal é a parenese em qualquer época. A segunda é a exegese oracular, pois a tradição dos oráculos era muito antiga e também popular. Para Young, inclusive, várias doutrinas patrísticas tiveram sua origem na exegese oracular, tais como: a noção de que a escritura foi inspirada pelo Espírito Santo e "ditada" para escribas; o sentido profético - cristológico - de toda a Escritura e o uso do método alegórico, tratando a escritura como um símbolo velado do mundo espiritual. A terceira é a análise lexical, incluindo nesta a etimologia e conhecimentos diversos necessários para 
a compreensão de um texto, como de geografia, cronologia, história, etc. A quarta é o comentário explanatório. A quinta é a expansão dedutiva. A sexta é a leitura mimética, que a autora divide em quatro tipos. A primeira é a mímese para a parenese exemplar, ou seja, identificar um modelo de conduta (por exemplo, Jó é um modelo de paciência). A segunda é a mímese para fornecer tipos proféticos (Jó também pode ser entendido como um tipo de Cristo). A terceira é a mímese para ver como o texto espelha a realidade "iconicamente" (modelo da escola de Antioquia). E a última é a mímese para descobrir a verdade oculta simbolicamente (modelo da escola de Alexandria). Portanto, para Young, eram esses dois últimos pontos que distinguiam de fato as duas escolas mencionadas, já que ambas compartilhavam todas as outras "estratégias de leitura" anteriores ${ }^{15}$.

A alegoria nos sermões de Padre Antônio Vieira 99

Mais ainda, Young mostra que os diferentes gêneros exegéticos empregados pelos Padres - homilias, comentários, apologias, etc. - apresentam em geral as mesmas "estratégias de leitura", inobstante o contexto de sua produção. Ao analisar as homilias de São João Crisóstomo (349 - 407), interressadas que eram em sua maioria em desenvolver a parenese, em desenhar paralelos entre duas histórias bíblicas, por exemplo, ou entre uma narrativa bíblica e a realidade de sua audiência, a fim de instilar nesta ensinamentos morais, a autora mostra que esse é um procedimento mimético. Young assinala que essas passagens não poderiam ser chamadas de tipológicas, especialmente a partir do conceito de tipologia empregado por Auerbach, uma vez que não se constata nessas passagens o caráter profético. Do mesmo modo, esse procedimento não pode ser chamado de alegórico, pois o texto deveria ser encarado como um pretexto para o ensinamento moral. Assim, Young acrescenta a categoria de "alegoria figural", de caráter essencialmente parenético, cujo objetivo era justamente o de fornecer padrões a partir dos quais as pessoas poderiam modelar suas vidas. Como afirma a autora, os tipos geralmente se correspondem por serem instâncias particulares de uma narrativa universal; a alegoria tende a abstrair verdades eternas de uma narrativa, perdendo

15 Young (ibid., p. 210-1) afirma que a diferença entre as escolas pode ser sintetizada na forma como elas abordam a representação do texto: em Antioquia, tinha-se uma abordagem "icônica", pois se buscava a semelhança da pessoa ou evento que o ícone representava; enquanto que em Alexandria tinha-se uma abordagem "simbólica", em que um signo, diferente do que é representado, toma seu lugar como a interpretação do texto a partir de uma analogia, que pode não ser muito clara, com o que é representado. 
Marcus

De Martini

a coerência narrativa. Mas ambas estão entrelaçadas em desenvolver uma leitura figural que possa mapear a jornada que constitui a vida de fé. Como conclui Young, antecedentes judaicos, bem como o tratamento profético do texto, contribuíram para a exegese figural cristã. No entanto, a mímese comumente atribuída à literatura no mundo greco-latino e as tradições retóricas de ler textos por seu valor moral e por sua habilidade para criar modelos para serem imitados também tiveram uma parte importante nesse processo. Assim, conclui Young (ibid., p. 264) que as "tendências figurais da exegese cristã foram o resultado de uma notável interpenetração cultural".

Do que se viu, pode-se então concluir o seguinte: a) apesar da ambiguidade do termo, "alegoria", e não "tipologia", ou mesmo "sentido típico", é, originalmente, no contexto cristão, o nome mais comum para o procedimento de interpretação através de tipos/figuras do AT, no sentido de aplicá-las a eventos do NT; b) portanto, o termo “tipologia" é anacrônico e não existe na literatura, pelo menos, até a Reforma; c) com o tempo, a alegoria passou a corresponder ao sentido espiritual das Escrituras, ou a um deles (como o que se costuma chamar de "tipológico"), em contraposição a seu sentido literal, histórico; d) no entanto, o caso da profecia é emblemático nesse sentido, pois o sentido literal da profecia seria seu cumprimento, fato este paradoxalmente revelado em linguagem figurada, o que demonstra que a relação entre sentido literal e sentido espiritual também pode ser dúbia, como se vê no caso do "sentido literal figurado" de Aquino; e) portanto, como afirma Young, a questão-chave é saber como o exegeta trata o referente textual, o que pode se dar de acordo com diversas estratégias de leitura, que passam a ser mais pertinentes à compreensão desses fenômenos interpretativos, sendo o tratamento do caráter mimético do texto sagrado, referente a coisas terrenas ou celestiais, o que realmente vai diferenciar essas leituras.

Por fim, pode-se alegar que o trabalho de Young se refere apenas aos escritos patrísticos. Contudo, foi nesse período que os conceitos de "alegoria", "tipo" e os quatro sentidos das escrituras surgiram. É a partir da leitura dos Padres da Igreja que eles vão se desenvolver posteriormente. E a eles Vieira se refere constantemente. Resta-nos, então, ver os sentidos desses termos na obra sermonística do jesuíta para compreender os empregos que lhes eram dados na parenética. 


\section{"Alegoria", "Tipo" e "Figura" nos Sermões de Vieira}

O uso da alegoria na parenética é fundamental, uma vez que o sermão atualiza a palavra de Deus para a audiência. Assim, as estratégias de acomodação do texto bíblico à realidade vivida pelos fiéis, por meio, no caso de Vieira e dos demais pregadores jesuítas de seu tempo, pelo menos, de uma retórica reaquecida pelos retores da Companhia, passam não apenas pelo conhecimento desse maquinário retórico, mas também do teológico, do qual não se separam ${ }^{16}$. Na esteira do que vimos na seção anterior, a alegoria pode assumir diversas facetas, e os termos relacionados a ela, tipo e figura, podem ter igualmente sentidos diferentes.

A leitura dos sermões de Vieira nos oferece uma gama muito ampla de exemplos. Fizemos aqui uma amostragem dos casos mais relevantes e reincidentes, pois nos interessava mais mapear as ocorrências de diferentes sentidos que quantificá-las com precisão ${ }^{17}$.

Dos três termos citados acima, o mais raramente empregado por Vieira é "tipo". Encontramos raras ocorrências nos sermões, não exatamente de "tipo", mas de "protótipo", palavra que Vieira deve ter colhido na lição dos Padres da Igreja, onde ela aparece com mais frequência escrita dessa forma. $O$ sentido com que a emprega, de fato, corresponde ao original grego, que é o de "modelo", tal como se vê na passagem abaixo, retirada do terceiro sermão da série Maria Rosa Mística:

\footnotetext{
São os reis como a serpente de Moisés levantada no meio do povo, que bastava porem os olhos nela, e ser vista, para dar saúde a quantos a viam: Pone eum pro signo: qui percussus aspexerit eum. São os reis como os protótipos e exemplares, que somente vistos, sem obrar, dirigem as ações do artífice, e aperfeiçoam as obras: Inspice, et fac secundum exemplar quod tibi in monte monstratum est. (grifos nossos).
}

Vieira aqui emprega uma analogia ao comparar os reis aos "protótipos e exemplares". Os "protótipos" são os modelos usados para que os artífices façam suas esculturas. Eis o sentido original do termo. Tendo sido empregado, porém, no contexto cristão, como vimos, seu sentido mudou. No entanto, seu sentido não é o de um "tipo" profético, propriamente dito,

16 Sobre a construção de um sermão e sobre os sermões de Vieira em particular, ver Pécora (2005 e 2008).

17 Os exemplos foram retirados da recente edição da obra completa de Vieira (2016). 
mas de um modelo de conduta. Os reis são - ou devem ser - um modelo moral para aqueles que os veem. Como os reis, assim também é Cristo, "rei dos reis", e são ainda os santos, cujas vidas se moldaram pela imitação do Filho de Deus. Essa lição é a que se colhe no Sermão de Santo Inácio:

Falando Deus de seu unigênito Filho por boca de Davi, diz que o gerou nos resplendores de todos os santos: In splendoribus sanctorum genui te. Estas palavras, ou se podem entender da geração eterna do Verbo antes da Encarnação, ou da geração temporal

Marcus

De Martini

102

do mesmo Verbo, enquanto encarnado. E neste segundo sentido as entendem Santo Agostinho, Tertuliano, Hesíquio, S. Justino, S. Próspero, S. Isidoro, e muitos outros. Diz pois o Eterno Padre, que quando mandou seu Filho ao mundo, o gerou nos resplendores de todos os santos, porque Cristo, como ensina a Teologia, não só foi a causa meritória de toda a graça e santidade, mas também a causa exemplar, e protótipo de todos os santos, enquanto todos foram santos à semelhança de Cristo, imitando nele e dele todas as virtudes e graças com que resplandeceram; e isto quer dizer: In splendoribus sanctorum. (grifo nosso).

Cristo, conforme afirma Vieira, foi "protótipo de todos os santos", já que serviu de modelo a eles todos. No entanto, fica claro que Vieira não emprega o termo no sentido construído a partir da Patrística, em que o tipo serve de modelo, de forma para o antitipo. Notamos anteriormente que o termo possuía um emprego fluido na obra dos $\mathrm{Pa}-$ dres da Igreja, mas que, geralmente, o tipo era preenchido pelo antitipo, que superava seu modelo, tanto que o tipo se tornava praticamente desnecessário. "Tipo" era como o molde que, depois de servir de modelo a uma estátua, pode ser descartado, emprego que se viu no excerto anterior. De forma análoga, nesse excerto, Vieira mostra que Cristo é um modelo a ser seguido, um exemplo. O uso que o jesuíta faz do termo, portanto, é claramente tropológico: Cristo é um "protótipo", um modelo de perfeição de virtudes que deve ser emulado. Assim finaliza Vieira:

Assim como todos os astros recebem a luz do sol, e cada um deles é juntamente um espelho e retrato resplandecente do mesmo rei dos planetas, assim todos os santos recebem de Cristo a graça, e do mesmo Cristo retratam em si todos os dotes e 
resplendores da santidade com que se ilustram. Por isso o anjo, quando anunciou a Encarnação, não disse: Qui nascetur ex te sanctus, senão: Quod nascetur ex te sanctum, porque Cristo não só foi santo, mas o Santo dos santos. O Santo dos santos, como fonte de toda a santidade por origem, e o Santo dos santos, como exemplar de toda a santidade para a imitação. (grifos nossos).

Mencionando o termo "protótipo" como exemplar de vida a ser seguida - verdadeiro convite à "imitatio Christi" -, e não em seu sentido profético, Vieira ilustra algo semelhante ao que Young chama de "alegoria figural", já que Cristo é mostrado como modelo de santidade e, portanto, como modelo a partir do qual os cristãos devem moldar suas vidas. Evidentemente, Vieira não poderia dizer que Cristo era um tipo, do qual

A alegoria nos sermões de Padre Antônio Vieira os santos seriam antitipos, pois ocorreria uma inversão na ordem da perfeição: os santos não podem ser mais santos do que Cristo. Ao contrário, o uso de protótipo está próximo ao de "antitipo", já que Cristo seria mesmo o tipo que recapitularia todos os outros tipos. De qualquer forma, o uso do termo não é mesmo profético, mas extrabíblico.

Essa compreensão de tipo como "exemplar", conforme apresentada por Vieira, torna-se mais clara pelo emprego que, logo adiante, no mesmo sermão, o jesuíta faz do termo "figura":

\footnotetext{
Antes de Cristo vir e aparecer no mundo, mandou diante o seu retrato, para que o conhecessem e amassem os homens. E qual foi o retrato de Cristo? Admirável caso ao nosso intento! 0 retrato de Cristo, como ensinam todos os Padres, foi um retrato composto de muitas figuras. Uma figura de Cristo foi Abel, outra figura de Cristo foi Noé. Uma figura foi Abraão, outra figura foi Isaac; uma figura José, outra figura Moisés; outra Sansão, outra Jó, outra Samuel, outra Davi, outra Salomão, e outros. Pois se o retratado era um só, e o retrato também um, como se retratou em tantas e tão diversas figuras? Porque as perfeições de Cristo, ainda em grau muito inferior, não se achavam nem se podiam achar juntas em um só homem; e como estavam divididas por muitos homens, por isso se retratou em muitas figuras. Era Cristo a mesma inocência: por isso se retratou em Abel. Era Cristo a mesma pureza: por isso se retratou em José. Era a mesma mansidão: por isso se retratou em Moisés. Era a mesma
} 
fortaleza: por isso se retratou em Sansão. Era a mesma caridade, a mesma obediência, a mesma paciência, a mesma constância, a mesma justiça, a mesma piedade, a mesma sabedoria: por isso se retratou em Abraão, em Isaac, em Noé, em Jó, em Samuel, em Davi, em Salomão. De sorte que sendo o retrato um só, estava dividido em muitas figuras, porque só em muitas figuras podiam caber as perfeições do retrato. Tal o retrato de Santo Inácio, como feito à semelhança de muitos: Et vos similes hominibus. Mas não me detenho na acomodação, porque estou vendo que

Marcus

De Martini aconteceu a Ezequiel com o retrato de Santo Inácio, o mesmo que ao pintor de Roma. (grifos nossos)

Na citação acima, Vieira emprega a forma latinizada de "typos" "figura" -, mas o sentido que lhe dá é diverso do que dera a "protótipo", que poderia ser compreendido originalmente como o mesmo termo. A interpretação dada por Vieira ao termo "figura" é, agora sim, o que comumente se entendeu como "tipo". Cristo foi um antitipo anunciado - ou foi "figurado", como usa Vieira - por vários "tipos", que foram preenchidos e superados nele. Logo de início, percebe-se que essa seria uma leitura "tipológica", ou alegórica no sentido paulino. Além disso, pode-se afirmar que o excerto apresenta a estratégia da "mímese para fornecer tipos proféticos", conforme Young. Atentemos, porém, ao desenvolvimento que Vieira dá às figuras de Cristo. Abel figurava a inocência, José a pureza, Moisés a mansidão, etc. Ora, em primeiro lugar, pode-se afirmar que tal leitura é, em sentido amplo, “alegórica”, já que retira das figuras bíblicas um conceito abstrato e não mais histórico-profético, o que corresponde à estratégia da "parenese exemplar" de Young. Esse sentido histórico-profético, "tipológico", reaparece no exemplo a seguir, retirado do Sermão de Nossa Senhora do Carmo, que é elucidativo quanto a isso:

Será prova não dificultosa desta maravilhosa excelência, um dos mais dificultosos lugares do Evangelho: Nolite putare quoniam veni solvere legem aut prophetas: non vem solvere, sed adimplere (Mt. 5, 17): Ninguém cuide de mim - diz Cristo - que vim desfazer a lei e os profetas, porque a vim guardar e cumprir. - É certo que Cristo veio desfazer a lei, porque em lugar da lei escrita, veio substituir a lei da graça. Pois, se Cristo veio desfazer a lei, como diz que a não veio desfazer, senão que a veio cumprir? Eu o direi: dai-me atenção. A 
lei de Moisés - não falando na parte judicial, que não pertence aqui - tinha duas partes: a cerimonial e a moral. A cerimonial, essa foi a que Cristo desfez, como se desfaz a sombra com a luz, a figura com o figurado, a promessa com o prometido, e a esperança com a posse. A parte moral, não a desfez Cristo, antes a aperfeiçoou, e de dois modos. 0 primeiro, declarando e tirando os abusos com que os fariseus a tinham depravado; o segundo, acrescentando-lhe os conselhos evangélicos, não com necessidade de preceito, mas como ornamento e coroa da mesma lei, para os que livremente a quisessem alcançar. (grifos nossos).

A alegoria nos sermões de Padre Antônio Vieira a clássica leitura "tipológica" dos Padres da Igreja, uma leitura cristológica, que coloca em Jesus o eixo entre os dois testamentos: "tipo" e "antitipo", "figura" e "figurado". o que parece se evidenciar, a partir das citações destacadas até agora, é que Vieira entendia "protótipo" e "figura" como conceitos diferentes. Pode-se afirmar que "figura" seria a palavra preferida por Vieira para se referir ao conceito de "tipo", enquanto que "protótipo" referir-se-ia a "antitipo". De qualquer modo, o uso que Vieira faz de "protótipo" relaciona-se sempre com um modelo moral, i.e., o jesuíta emprega-o tropologicamente, uso mais adequado à parenética. Entendendo "figura" como retrato que prenuncia algo futuro, "tipo", Vieira entende o termo como "prefiguração profética de realidades", o que caracteriza o que comumente se entende como uma leitura "tipológica", mais característica de seus textos exegéticos. No entanto, como vimos no caso anterior, esses dois sentidos podem confluir em alguns momentos, sendo Cristo protótipo de perfeição e antitipo profético. No fundo, são duas faces da mesma moeda, o que parece dar razão a Young, no sentido de que o objetivo parenético do texto faz o pregador lançar mão de estratégias diferentes. Isso não quer dizer que Vieira não tinha ideia clara desses conceitos. A leitura paulina da relação entre AT e NT, conforme explicitada anteriormente, é reproduzida por ele no terceiro sermão da série Maria Rosa Mística:

\footnotetext{
Para inteligência do que digo, havemos de supor, com S. Paulo, que tudo o que sucedia, pela maior parte, ou se fazia no tempo dos patriarcas e da lei escrita, era representação e figura do que depois havia de ser no tempo da lei da graça: Haec autem omnia in
} 
Marcus

De Martini

106

figura contingebant illis. Este é o princípio fundamental por que a muitas coisas daquele tempo não achamos a razão de a fazerem, antes parecem feitas contra toda a razão, ainda entre homens santos. E a razão de se lhes não achar razão é porque a razão da figura não está na figura, senão no figurado. Se víssemos que um pintor pintava um rei pastando entre os animais e comendo feno, e outro com o braço esquerdo muito curto, e o direito muito comprido, parecer-nos-ia isto uma grande impropriedade. Mas se o pintor nos respondesse que no primeiro retratava a Nabucodonosor, e no segundo a Artaxerxes, que pela desigualdade dos braços se chamou Longimano, acharíamos a razão da pintura, não nos retratos, senão nos retratados. Da mesma maneira em outros casos do Testamento Velho. Que coisa mais fora de razão que levar Jacó o morgado a Esaú, sendo Esaú o primogênito, e Jacó o filho segundo? E que maior sem-razão outra vez, que servir Jacó sete anos por Raquel, e darem-lhe em lugar de Raquel a Lia? Mas, se olharmos para os originais destas mesmas figuras, acharemos neles as razões que nelas de nenhum modo apareciam. Jacó e Lia representavam o povo gentílico. Esaú e Raquel o judaico. E levou Jacó o morgado a Esaú, porque ó morgado da fé e da graça, que era do povo judaico que foi o primeiro, se havia de passar ao povo gentílico, que é o segundo. E sendo Jacó figura de Cristo, que serviu pela sua Raquel, que era o povo judaico, como ele mesmo disse: Non sum missus nisi ad oves, quae perierunt domus Israel - desposou-se primeiro com Lia, que é o povo gentílico, e depois se há de desposar também com Raquel, que é o povo judaico, porque como diz S. Paulo: Donec plenitudo gentium intraret, et sic omnis Israel salvus fieret. (grifos nossos)

A passagem ilustra a ideia tecida a partir dos Padres da Igreja de superação do AT pelo NT. O que ocorreu no tempo da Lei Escrita, ocorreu como "figura" da Lei da Graça. Nisso encontrava-se seu sentido. Como pondera Vieira, a razão de ser da "figura" está no "figurado", i.e., o "tipo" é moldado de forma a se adequar ao "antitipo". Como afirma Dahan (2005, p. 221), esse procedimento é próprio da "alegoria”, em que o "significado" produz a significação para o "significante". Esse raciocínio é eminentemente "icônico", como destaca Young, típico da exegese de Antioquia. O que se busca é a semelhança entre dois personagens de 
forma retrospectiva. É o figurado que faz com que se entenda a figura; é o significado - só descoberto depois - que torna o significante claro; é o referente histórico que torna o referente anterior, também histórico, coerente. Contudo, essa coerência só é possível tendo como fundamento o cumprimento das profecias, o sentido de "recapitulação", que repousa em Cristo. Além disso, esse raciocínio possibilita compreender passagens aparentemente absurdas, i.e., passagens que são absurdas em si, mas que não são absurdas em relação à economia divina, para usar o termo de Irineu. Do mesmo modo, essa observação vai ao encontro da tendência originalmente grega de justificar o absurdo de alguns textos clássicos por meio de uma leitura alegórica deles. Ainda, segundo as regras interpretativas de Agostinho, o que for aparentemente contrário à mensagem cristológica, deve ser lido alegoricamente. É essa verticalidade, conforme Auerbach, que dá coerência às Escrituras. Na fórmula clássica de Agostinho de Dácia, a alegoria ensina no que acreditar ${ }^{18}$.

Como se vê, há uma zona nebulosa, que parece interpor-se e borrar as fronteiras entre os conceitos de "protótipo" e de "figura". Ao empregar este último, Vieira alarga sua abrangência, uma vez que entende "figura" não só no sentido propriamente tipológico - relação entre AT e NT -, mas também, seguindo tendência que se acirrou a partir da Idade Média, como "modelo" que se pode aplicar a realidades de qualquer tempo. Tal é o emprego feito pelo jesuíta no Sermão das Lágrimas de São Pedro:

Esta é a lastimosa e gloriosa representação com que a Igreja dá feliz princípio neste dia a uma semana que devera ser santa na compunção, como é santa no nome. Faltando água no deserto a um povo, que era figura deste nosso, chegou-se Moisés a um penhasco, deu-lhe um golpe com a vara, e não saiu água: deu o segundo golpe, e saíram rios: Egressae sunt aquae laigissimae (Num. 20, 11). (grifo nosso)

Vieira compara o povo israelita ao povo português. Essa comparação foi apresentada várias vezes pelo jesuíta também em sua obra profética. 0 povo português repetiu, por analogia, no domínio espanhol, o cativeiro dos hebreus. Do mesmo modo que estes eram o povo

18 "Littera gesta docet, quid credas allegoria,/ Moralis quid agas, quo tendas anagogia" (DAHAN, op. cit., p. 221). 
escolhido na lei antiga, os portugueses eram o povo escolhido do tempo em que viviam os que escutavam a prédica. Assim, a leitura dita aqui "figural" de Vieira extravasa os limites bíblicos e se atualiza diante dos olhos do auditório. Embora se constate um caráter profético no excerto, a finalidade parenética de tal procedimento também é evidente: "devemos fazer o que eles fizeram porque a história é análoga". Essa analogia mostra, não que a história se repente identicamente, o que não seria estritamente adequado à concepção cristã de tempo, mas como analogia do Eterno, alegoricamente. Acreditamos que grande parte - senão o Marcus total - das estratégias concionatórias de Vieira repousa na confluência De Martini entre as estratégias proféticas e modelares das passagens bíblicas de que se vale para pregar. Não há uma separação entre elas, ao mesmo 108 tempo em que não há identidade total. Isso porque, enquanto "tipos" ou "figuras", cabe ao pregador “alegorizá-las", isto é, interpretá-las segundo as estratégias pertinentes a cada situação enunciativa, muitas vezes utilizando estratégias de leitura diferentes cumulativamente.

Retomando a leitura que Vieira fizera no caso das figuras veterotestamentárias de Cristo, pode-se afirmar que a relação entre "figura" e "figurado" não é biunívoca. Várias "figuras" podem se referir ao mesmo referente "figurado". É o que se vê no excerto do Sermão de Nossa Senhora da Graça, de 1652, mostrado a seguir:

Ora, eu buscando a causa desta misteriosa impropriedade - que não pode ser sem mistério - e reparando com atenção na cruz levantada, e na Senhora em pé junto a ela, representou-se-me a cruz naquelas duas figuras em que tantas vezes a vemos significada no Testamento Velho: em figura de vara, e em figura de balança. Figura da cruz foi a vara de José, adorada de Jacó, porque já então o sagrado e consagrado madeiro começava a ser venerado com adoração de latria (Gên. 47. 31; LXX. Hebr. 11, 21). Figura da cruz foi a vara de Arão florescente, porque havia de ter a cruz; por remate, o título de Nazareno, que quer dizer florido (Núm. 17, 8). Figura da cruz foi a vara que tocou e acendeu o sacrifício de Gedeão, porque com seu contato santificou o Redentor a Cruz, e nela consumou o maior sacrifício (Jz. 6, 21). Figura da cruz foi a vara de Assuero que, estendida sobre Ester, a livrou a ela e a todo seu povo da tirania de Amã, como a cruz a nós todos da sentença geral da morte (Est. 5, 2). Figura da cruz foi a vara que saiu de Sion para dominar todas as 
gentes, e as pôr - como as tem posto a cruz - sujeitas e rendidas aos pés de Cristo (SI. 109, 8). Figura foi enfim da cruz a vara de Moisés prodigiosa, a vara de Jônatas, que vertia mel, e sobre todas, a vara de Jessé, de cujas raízes nasceu o fruto coroado e bendito do ventre sacratíssimo de Maria (Êx. 4, 2; 1 Rs. 14, 27; Is. 11, 1).

A passagem pode parecer confusa para uma época em que se pensa as questões linguísticas a partir das relações entre significante e significado. No caso acima, vê-se que há como que vários significantes

A alegoria nos sermões de Padre Antônio Vieira muita frequência por Vieira, nos mais diferentes contextos e para os mais diferentes propósitos.

Vieira esclarece, no segundo sermão da série Maria Rosa Mística, que essa repetição de figuras serve a um propósito:

Pois, se o mesmo mundo o criou Deus, e fez de uma vez estoutras obras suas, por que as não mostra em uma só visão ou figura, senão em duas? Porque no fazer obra Deus segundo as medidas da sua onipotência no mostrar e dar a conhecer, segundo a capacidade da nossa vista. Porque nós não o somos capazes de ver tudo de uma vez, supre Deus na Segunda ideia o que faltou na primeira.

Deus, reconhecendo a incapacidade humana de abarcar com seu entendimento toda a complexidade de sua obra, reparte-a em várias figuras, correspondentes a revelações diferentes, mas também em várias figuras correspondentes à mesma revelação. Por sua vez, essas figuras repetidas relacionam-se por semelhança, mas também por complementaridade.

A palavra "figura" apresenta ainda outros três sentidos nos sermões. O primeiro é o de "personagem", especificamente de personagem teatral. Vieira a emprega diversas vezes. Citemos um exemplo do Sermão da Sexagésima:

Na comédia o rei veste como rei, e fala como rei; o lacaio, veste como lacaio, e fala como lacaio; o rústico veste como rústico, e fala como rústico; mas um pregador, vestir como religioso e falar como... não o quero dizer, por reverência do lugar. Já que o 
púlpito é teatro, e o sermão comédia se quer, não faremos bem a figura? Não dirão as palavras com o vestido e com o ofício? (grifo nosso).

O mesmo ocorre mais claramente no excerto abaixo:

Marcus

De Martini
S. Paulo, descrevendo este mundo, para nos desafeiçoar de suas vaidades, diz que é como um teatro em que as figuras cada uma entra a representar o seu papel, e passa: Praeterit enim figura hujus mundi. Não diz o Apóstolo que passa o mundo, senão as figuras: porque as figuras vão-se e o teatro fica.

Esse emprego do termo é emblemático, porque a relação da "figura", a personagem ${ }^{19}$, com o "ser" que o ator interpreta, ou mesmo com seu modelo ("protótipo"), é uma relação entre a falsidade e a realidade. Há obviamente uma representação. Esse emprego mostra como o sentido das "figuras" veterotestamentárias é realmente o de "sombras" ("umbra") de Cristo, como algo "menos real", menos perfeito. O emprego da palavra "figura" como sinônimo de personagem salienta esse aspecto de imitação que a figura faz do figurado, como o personagem faz do ser "real" (que existe ou existiu como personagem histórico ou que existe como "tipo humano") levado ao palco, por sua vez, alegoria do mundo.

O segundo sentido é o de "forma física", muitas vezes o de "forma geométrica". Abaixo segue um excerto do Sermão da Quinta-feira da Quaresma:

\begin{abstract}
É filosofia bem-fundada de Filo Hebreu que os olhos não só vêem a cor, senão a cor, a figura e o movimento, e em todas estas três coisas errou a primeira vista daquele homem, representando-lhe os homens como árvores. Errou na cor, porque as árvores são verdes e os homens, cada um é da cor de seu rosto e do seu vestido. Errou na figura, porque as árvores têm um pé, e os homens dois; os homens têm dois braços e as árvores muitos.
\end{abstract}

19 É bom recordar que a própria noção de personagem-tipo ou típico remete a esses personagens de estoque que correspondem a determinados "tipos humanos", conforme definidos a partir dos caracteres delineados por Teofrasto ( 371 - 287 a.C.) - o colérico, o misantropo, o vaidoso, etc.- e que dariam origem a personagens típicos da Comédia Nova Grega. 
Por fim, o último sentido é o de figura de linguagem, termo proveniente da Retórica:

Este texto tem dado grande trabalho aos expositores, e todos concordam em que falou aqui o profeta pela figura que os retóricos chamam metonímia, tomando a qualidade pela pessoa e o pecado pelo pecador, porque o pecador pode deixar de ser pecador, e ser justo, e o pecado nunca pode deixar de ser pecado.

A alegoria nos sermões de

As relações, como vemos, muitas vezes confusas entre esses termos podem ser, por fim, constatas no excerto abaixo:

Disse que o abriria o Leão da tribo de Judá, que é Cristo, o qual logo apareceu em figura de cordeiro, em pé, e como morto: Agnum stantem, tanquam occisum (Apc. 5, 6), tudo com o mesmo mistério. Em figura de cordeiro, porque esta obra, sendo de seu poder, é muito mais de sua benignidade e misericórdia. Em pé, e como morto, porque Cristo morreu na cruz, não jazendo, senão em pé, e da cruz, acresceu a bula o nome de Cruzada. E finalmente não morto, senão como morto, porque correr sangue do lado de Cristo (o que só acontece aos vivos) foi ação de faculdade vital e vivificante, como gravemente notou S. Hipólito: Ut ne ipsum corpus mortuum aliis simile appareat, nobis autem ea, quae sunt vitae causa, possit profundere. Correu sangue do lado de Cristo morto, - diz este antiquíssimo Padre, - para que entendêssemos que o mesmo lado, ainda morto, tinha potência de vivificar, e que dele manavam todas as graças que nos haviam de dar vida. (grifos nossos).

Ao se referir à aparição de Cristo na figura de cordeiro, Vieira emprega o termo como "figura profética", mas também se pode entender o termo como "forma" de cordeiro. De qualquer modo, o caráter de ambas as interpretações é mimético, como são todos os empregos vistos até aqui do termo "figura". É sempre uma relação de semelhança entre dois termos que os aproxima pela interpretação "alegórica". o mesmo vale para "protótipo". Pela comparação entre duas situações diferentes, entre duas realidades diferentes, separadas no tempo, mas aproximadas por sua semelhança, constata-se o aspecto mítico da leitura figural,
Padre Antônio

Vieira 
pois subjaz a ela a ideia de repetição de modelos sagrados do passado e de respeito também a eles, que devem ser atualizados constantemente pelo ritual (cf. FRYE, op. cit., p. 49). Mas façamos uma ressalva: não a repetição do mesmo, mas da presença de Deus no mundo, percebida na analogia que as coisas guardam com a ideia divina como obra da Providência. Nesse caso, a leitura alegórica, seja ela profética ou tropológica, ou mesmo anagógica, mostra a perenidade e a presença do passado no presente e no futuro, já que em todos os tempos percebe-se a presença do eterno. Esquecer isso é perder-se, é cegar-se.

Marcus Já o termo "alegoria" apresenta uma relação próxima com "figuDe Martini ra", ainda que não idêntica. Antes de analisá-lo, é interessante mencionar a descrição que Raphael Bluteau dá aos termos analisados até aqui 112 em seu Diccionario da lingua portuguesa (1789), o primeiro de nosso idioma. Protótipo é definido ali como "modelo, exemplar, molde". Quanto a "figura", os exemplos que dá Bluteau correspondem ao uso do vocábulo por Vieira. Em alguns locais, o exemplo ilustrativo dado pelo autor são citações do jesuíta. "Typo" é definido como "letra e fôrma de imprimir", ou como sinônimo de figura ou símbolo, o que também corresponde ao uso feito por Vieira, enquanto "típico" é definido como sinônimo de sentido alegórico. Assim, é bem provável que Bluteau tenha composto esses verbetes especialmente a partir da consulta aos sermões de Vieira, o que se confirma com a definição de "alegoria". Bluteau caracteriza "alegoria" como uma figura retórica - uma metáfora continuada, sua noção clássica -, remetendo o leitor ao uso que dela faz Vieira no Sermão da Sexagésima.

Notai uma alegoria própria da nossa língua. O trigo do semeador, ainda que caiu quatro vezes, só de três nasceu; para o sermão vir nascendo, há-de ter três modos de cair: há-de cair com queda, há-de cair com cadência há-de cair com caso. A queda é para as coisas, a cadência para as palavras, o caso para a disposição. A queda é para as coisas porque hão-de vir bem trazidas e em seu lugar; hão-de ter queda. A cadência é para as palavras, porque não hão-de ser escabrosas nem dissonantes; hão-de ter cadência. $O$ caso é para a disposição, porque há-de ser tão natural e tão desafectada que pareça caso e não estudo: Cecidit, cecidit, cecidit. (SI: 39) 
Tendo como fonte a Parábola do Semeador, Vieira extrai dela conceitos que direcionam sua pregação e ilustram sua argumentação. Já que o texto bíblico é uma parábola, valendo-se de uma linguagem metafórica, o jesuíta interpreta-a a seu modo, "acomodando" a mensagem de Cristo ao contexto da pregação. Todo texto bíblico que emprega narrativas desse tipo guarda em si um ensinamento oculto. A leitura alegórica é o que permite revelar essa verdade.

E se não, pergunto: por que se transformou ali o boi, e não o leão? A alegorianos sermões de A rudeza ou bruteza do leão, como a do boi, ambas são de quatro Padre Antônio pés. Pois, se o leão igualmente andava junto com o homem e com Vieira a águia, por que se não transformou também em querubim? Porque o boi é animal sujeito e humilde, o leão é inchado e soberbo, e, por mais racional que seja o entendimento do homem, e mais sublime que seja a agudeza da águia, onde há inchação e soberba, nem o homem, nem a águia podem introduzir a sua forma. Esta é a alegoria do famoso carro, o qual, para maior glória de Catarina, também hoje transformou os leões. (grifo nosso)

Assim, a alegoria é tanto o processo de criação de uma narrativa metafórica - a "alegorese" - como a "acomodação" dessa narrativa a uma situação concreta, histórica, a qual é iluminada pela interpretação do exegeta.

O primeiro carmelita foi o primeiro que logrou estes alimentos, e tomou em figura a posse deles. Fugiu Elias para o deserto, lançou-se ao pé de uma árvore, adormeceu, acordou-o um anjo e deu-lhe pão para que comesse. Comeu Elias, tornou a adormecer, e tornou o anjo a acordá-lo e a dar-lhe mais pão, e comeu outra vez. É comum alegoria dos Padres, que este pão representava o Santíssimo Sacramento. (grifos nossos)

A "alegoria dos Padres" é a leitura ligada ao sentido espiritual das Escrituras que eles fizeram. Por isso, a leitura alegórica relaciona-se com as "figuras", que dela fazem parte.

Santo Agostinho, Santo Ambrósio, S. Gregório, e todos os padres, concordemente entendem que a famosa funda de Davi, se foi maravilhosa pelo que obrou, mais misteriosa foi ainda pelo 
que significava. E entre todas as alegorias com que até agora se tem declarado seus mistérios, nenhuma lhe quadra melhor, e com maiores fundamentos da mesma Escritura, que ser figura profética do Rosário. (grifos nossos)

O episódio da funda de Davi compreende um relato histórico do povo judeu. Tal é o sentido histórico ou literal das Escrituras. Porém, seu significado transcende o próprio evento de que faz parte, porque também simboliza um mistério. A funda de Davi é uma figura do RosáMarcus rio, "sombra" de uma coisa futura, e por isso profética.

De Martini

Como vimos, o sentidos das escrituras não são excludentes, mas complementares. As diferentes leituras convivem entre si e iluminam-se.

Porei - diz Deus - o meu arco nas nuvens, e este será o sinal entre mim e o mundo, da promessa e mercê que lhe fiz de o livrar para sempre de outro dilúvio. - E que arco é este de que Deus fala e chama seu? Historicamente é o Íris de três cores que por reflexão dos raios do sol aparecem nas nuvens. Alegoricamente é a Virgem Maria que concebeu em si o sol Divino, e de quem recebeu toda a graça. Assim o dizem S. Efrém, Santo Antônio, S. Bernardino de Sena. (grifos nossos)

Vieira interpreta o arco-íris de dois modos. No sentido literal, histórico, é o fenômeno físico visível; no sentido alegórico, neste caso, no primeiro sentido espiritual, segundo São Tomás de Aquino, é uma figura da Virgem Maria. A complementaridade entre os procedimentos interpretativos também é constatada pelo excerto abaixo:

\footnotetext{
Saibamos agora: e esta Sara, quem era? Dizem as alegorias que era figura da Virgem Maria, Senhora nossa, e se confirma como seu próprio nome, porque Sara quer dizer domina, a senhora.
}

Mais uma vez, "alegoria” é sinônimo de interpretação alegórica, daí seu emprego no plural. Ao interpretar a personagem bíblica Sara, Vieira reporta as alegorias que a entendem como figura profética de Maria, caracterizando o que chamaríamos de uma leitura alegórica ou "tipológica". No entando, confirma sua leitura com a análise etimológica do nome da esposa de Abraão, que é uma das estratégias de interpretação mencionadas 
por Young. Assim, há uma interpretação profética do referente, de base mimética (Sara se assemelha à Virgem Maria), mas também há uma interpretação etimológica, do nome. $\mathrm{O}$ "significante" confirma o significado.

\begin{abstract}
Naquela famosa carroça, que descreve o profeta Ezequiel, na qual ia ou era levado Deus, o artifício das rodas era admirável, porque dentro de uma roda estava ou se revolvia outra roda: Rota in medio rotae. E que duas rodas eram estas? Uma era a roda do tempo, e a outra a roda da eternidade, diz Santo Ambrósio: Rota in medio rotae, veluti vita intra vitam, quod in hac vita corporis, vitae volvatur usus aeternae. A roda do tempo é pequena e breve; a roda da eternidade é grandíssima e amplíssima, e, contudo, a roda do tempo encerra e revolve dentro em si a roda da eter-
\end{abstract}

A alegoria nos sermões de Padre Antônio Vieira

A passagem acima é muito interessante. A partir do relato da carroça de Ezequiel, que apresentava uma roda dentro de outra, Vieira faz três - senão quatro - interpretações diferentes. Em primeiro lugar, as rodas representam o tempo e a eternidade, ou seja, as imagens se referem a conceitos abstratos, o que caracteriza uma leitura alegórica propriamente dita, já que proveniente de Santo Ambrósio, mestre de Agostinho, influenciado pela escola alexandrina ("alegorizante"). Mais ainda, a "alegoria" das rodas mostra um ensinamento quanto ao pós-vida, conforme a leitura de Santo Ambrósio trazida por Vieira: a eternidade de alguém corresponderá à vida que teve, o que indica uma interpretação tropológica, mas também, não deixa de ser, anagógica. Por fim, as rodas também representam Cristo no útero de Maria, o que configura uma leitura profética, a que chamaríamos de "tipológica". As rodas figuram que a eternidade está dentro do tempo, assim como a vida das pessoas, que partilham da eternidade de Deus, e como Cristo esteve dentro de Maria. 
Essa espécie de "multirreferencialidade" é o que subjaz ao "discurso engenhoso" característico do "barroco", de acordo com o clássico estudo de Antonio José Saraiva (1980). Para este último, o “discurso engenhoso" é aquele que "se ordena em função da 'agudeza", conforme prescrevia as obras de Baltasar Grácian ou Emanuelle Tesauro. Contrariamente ao "discurso clássico", em que as palavras devem ter um sentido preciso, já que é um discurso comprometido com a lógica e a clareza; no discurso engenhoso, as palavras são escorregadias e podem significar de diversos modos: pelo seu significado, mas tamMarcus bém por sua etimologia, por sua estrutura fônica, pelas letras, etc. No De Martini entanto, muito embora Saraiva não o mencione, o procedimento não é estranho diante dos pressupostos linguísticos retirados de Santo Agostinho. Vieira repete diversas vezes a lição agostiniana: "uma coisa é o que as palavras soam, outra o que significam". Evidentemente que tal característica da linguagem foi empregada expressivamente pelo pregador e por outros autores do período. No caso de Vieira, porém, isso não quer dizer que fosse concebida, às vezes, como artificiosa e meramente adornativa. Saraiva parece insinuar que as imagens empregadas por Vieira são "a própria realidade", e não somente metáfora ou comparação, apenas quando retiradas das Escrituras. Ora, a retórica de Vieira é a retórica de um pregador, voltada, pois, à conversão dos fiéis com base no ensinamento divino. O emprego de elementos retóricos que faz tem como alvo elucidar a palavra divina para o auditório. Vieira não se via como um "poeta", no sentido de que não criava "fábulas". Através dos sermões, Vieira falava a verdade, já que seu referente final é sempre Deus, que é a realidade última. O uso da alegoria, conforme vimos, aponta para essa direção. Como afirmam Pécora e Hansen, a "agudeza" não é apenas uma técnica retórica que possa se divorciar de seu uso hermenêutico, intimamente conectado com determinada concepção teológica:

\footnotetext{
(...) a agudeza não deve ser entendida neoclassicamente como a afectação de um jogo de palavras fantástico e inconseqüente, que não teria nenhuma relação com o real. Sendo um típico discreto seiscentista, Vieira pauta toda a fantasia com o juízo, aristotelicamente ordenado como prudência; logo, por mais fantásticas que possam aparecer para o leitor contemporâneo, que provavelmente não mais vive a experiência do sagrado, suas
} 
agudezas revelam a universal mediação de tudo e todos pela luz natural da Graça inata e sua variedade é sempre espelho político da Unidade ou ornato da Identidade. (HANSEN, s/d)

Acreditamos que os exemplos que demos até agora confirmam essa hipótese.

\section{Conclusão}

O que permite ao pregador fazer seu papel corretamente é empregar com adequação a leitura alegórica, associada sim aos recursos retóricos a sua disposição; não subordinada a eles, mas os subordinando. Não apenas a leitura "tipológica", revelando aos ouvintes os futuros, ou confirmando a presença da Providência, mas também, e principalmente, a leitura moral, para que aprendam os modelos - "protótipos" - a serem imitados pelo bom cristão. Por isso, a relevância da noção de Young de "alegoria figural", que parece sintetizar o emprego concionatório da palavra divina. Ao revelar o trabalho da Providência para o auditório, o pregador se vale dos mais diversos recursos alegóricos. Por isso, parece-nos que o emprego subsidiário da noção de "estratégias de leitura", conforme Young, pode nos auxiliar mais na compreensão dos diferentes usos implicados na noção de alegoria. Como vimos, os conceitos de alegoria, tipo e figura são utilizados difusamente, sendo sua exata compreensão algo complicado, senão impossível ou, pelo menos, pouco profícuo.

Permanece, conforme afirma Young, o caráter mimético da alegoria, como rebento híbrido da cultura greco-latina e da judaico-cristã. Através da busca por semelhanças, de eventos do AT com os do NT, de relatos bíblicos com a realidade contemporânea, da hagiografia de algum santo com a vida do bom cristão, o pregador usa "alegorias" ${ }^{20}$. Seja o termo entendido como a interpretação de uma passagem reveladora ou como a acomodação a outra situação, tudo são alegorias. Partindo sempre de uma passagem bíblica, escolhida conforme a circunstância de enuncia-

20 Como ensina Foucault, a busca por semelhanças foi a base para a construção do saber ocidental até fins do século XVI (2007, p. 25). Contudo, Hansen salienta que "Foucault não atravessa os Pireneus. Em lugares tridentinos como Roma, Nápoles, a Espanha, Portugal e as colônias ibéricas da América, as apropriações católicas de Aristóteles, Santo Agostinho, Santo Tomás de Aquino e a infinidade de doutores da Igreja continuaram doutrinando a similitude como infinitismo da lei natural da Graça inata até o final do século XVIII, doutrinando a lei eterna de Deus como fundamento do poder de Estado, da linguagem e das artes" (MOREIRA et ROCHA, 2005, p. 15). 
ção, ou, mais comumente, conforme a data em que o sermão é pregado, que trabalho resta ao pregador senão explicá-la, interpretá-la, significá-la para os ouvintes? Todos os sentidos das Escrituras são movidos para que o sermão possa "frutificar". Assim, acreditamos que seja mais conveniente à análise dos sermões de Vieira compreender os fins aos quais os procedimentos alegóricos, em sentido amplo, são mobilizados retoricamente, do que simplesmente classificá-los como alegorias.

Marcus

REFERÊNCIAS

De Martini

AUERBACH, Erich. Figura. São Paulo: Ática, 1997.

118

. Mimesis. São Paulo: Perspectiva, 1994.

CEIA, Carlos. Sobre o conceito de alegoria. In: Matraga, n. 10, outubro de 1998.

DAHAN, Gilbert. L'allégorie dans l'exégèse chrétienne de la Bible au Moyen Age. In: Allégorie des poètes, allégorie des philosophes: études sur la poétique et l'herméneutique de l'allégorie de l'antiquité à la réforme : table ronde internationale de l'Institut des traditions textuelles, Fédération de recherche 33 du CNRS. Actes publiés sous la direction de Gilbert Dahan et Richard Goulet.. Paris : Vrin, 2005.

DANIÉLOU, Jean. Qu'est-ce que la Typologie? In: AUVRAY, Paul et al. L'Ancien Testament et les Chrétiens. Paris: Les Éditions du CERF, 1951, p. 199-205.

From Shadows to Reality: Studies in the Biblical Typology of the Fathers. Westminster, MA, USA: The Newman Press, 1960.

EVANS, Craig A. The Christian Adoption of The Old Testament. In: BYRNE, Peter; HOULDEN, Leslie (ed.). Companion Encyclopedia of Theology. New York: Routledge, 1995.

FOUCAUlT, Michel. As Palavras e as Coisas: uma arqueologia das ciências humanas. 9. ed. São Paulo: Martins Fontes, 2007. 
FRYE, Northrop. The Great Code: the Bible and Literature. New York, USA: Harcourt Brace Jovanovich Publishers, 1982.

GALDON, Joseph A., S.J. Typology and Seventeenth-Century Literature. The Hague, The Netherlands: Mouton, 1975.

GOPPELT, Leonhard. Typos: The Typological Interpretation of the Old Testament in the New. Grand Rapids, Michigan, USA: William B. Eerdmans Publishing Company, 1982.

A alegoria nos sermões de Padre Antônio Vieira

. Vieira: tempo, alegoria e história. In: Brotéria, 145, 4, 1997, p. 541-556.

. Vieira: tempo, história e providencialismo figural. (Mimeo.). s/d.

LUBAC, Henri de. "Typologie" et "Allégorisme". In: Recherches de Science Religieuse, v. 34, 1947, pp. 180-226.

MONTAGUE, George T. Understanding the Bible: a basic introduction to biblical interpretation. Rev. \& expanded ed. New Jersey: Paulist Press, 2007.

MOREIRA, Marcello; ROCHA, Marília Librandi. (orgs.). Questões para João Adolfo Hansen. In: FLOEMA - Caderno de Teoria e História Literária, Vitória da Conquista, Ano I, n. 1 p. 11-25 2005.

O'KEEFE, John J.; RENO, R.R. Sanctified Vision an introduction to early Christian Interpretation of the Bible. Baltimore, MA, USA: Johns Hopkins University Press, 2005.

PÉCORA, Alcir. Para Ler Vieira: As 3 Pontas das Analogias nos Sermões. In: Floema. Caderno de Teoria e História Literária. Ano I, n. 1, Vitória da Conquista, 2005, p. 29-36.

- Teatro do sacramento: a unidade teológico-retórico-política dos sermões de Antonio Vieira. Campinas: UNICAMP, [1994], 2008. 
SARAIVA, António José. 0 discurso engenhoso: estudos sobre Vieira e outros autores barrocos. São Paulo: Perspectiva, 1980.

SILVA, Antônio de Morais, 1755-1824; BLUTEAU, Rafael, 1638-1734. Diccionario da lingua portugueza composto pelo padre D. Rafael Bluteau, reformado, e accrescentado por Antonio de Moraes Silva natural do Rio de Janeiro. 2. V. Lisboa : Na Officina de Simão Thaddeo Ferreira, 1789.

Marcus SIMONETTI, Manlio. Biblical Interpretation in the Early Church: De Martini an historical introduction to Patristic exegesis. Edinburgh, UK: T\&T Clark, 1994.

VIEIRA, Antônio. Obra Completa Padre Antônio Vieira. (direção José Eduardo Franco, Pedro Calafate). São Paulo: Edições Loyola, 2016.

WHITMAN, Jon. Allegory: the dynamics of an ancient and medieval technique. Cambridge, Massachussets: Harvard University Press, 1987.

WOOLLCOMBE, K.J. The biblical origins and patristic development of typology. In: LAMPE, G.W. H.; Essays on Typology. London: SCM Press, 1957.

YOUNG, Frances M. Biblical Exegesis and the Formation of Christian Culture. Cambridge, UK: Cambridge University of Press, 1997, p. 9 e segs. 